\title{
HMGN4 Gene
}

National Cancer Institute

\section{Source}

National Cancer Institute. HMGN4 Gene. NCI Thesaurus. Code C20584.

This gene plays a role in chromatin remodeling and enhancing gene transcription from chromatin templates. 